\title{
Influence of Intellectual Capital on Company Growth with Company Performance as Intervening Variables \\ ${ }^{1}$ Verani Carolina, ${ }^{2}$ Debbianita, ${ }^{3}$ Maria Natalia \\ ${ }^{1,2,3}$ Maranatha Christian University \\ debbianita@gmail.com
}

\begin{abstract}
Intellectual capital is one of the knowledge assets owned by a company. This study aims to determine whether intellectual capital has a positive influence on the growth of companies with company performance as an intervening variable. This research takes a sample of companies engaged in hotels, restaurants, and tourism where the sector is one of the critical economic sectors in Indonesia. It is expected that intellectual capital will increase innovation so that it can attract consumers who ultimately improve performance. The data used in this study are financial data for 2009-2015 obtained from the financial statements of each company. The method used is a panel that is processed using e views 6 .

Keywords: company growth, company performance, intellectual capital

JEL : M41

DOI : :10.24002/kinerja.v22i2.2023

Received : 02/27/2019 Reviewed: 04/09/2019 Final Version: 09/25/2019
\end{abstract}

\section{INTRODUCTION}

There have been significant changes in this century where globalization, technological innovation, and intense business competition have made companies change the way they do business. To be able to survive in the tight competition that exists, the company changes the strategy of business based on labor (laborbased business) towards knowledge-based business, with science as the primary characteristic (Sawarjuwono and Kadir, 2003). Intellectual capital, knowledge capital, knowledge organizations, learning organizations, organizational learning, the information age, knowledge era, information assets. Intangible assets, intangible management, hidden value, and human capital are terms that are used to show the knowledge assets of management (Bontis, 2001).

With a knowledge-based business, the success of a company will depend on creating transformation and capitalization from the knowledge itself so that conventional capital such as natural resources, financial resources, and other physical assets become less important (Sawarjuwono and Kadir, 2003). 
At present, the term intellectual capital become one of the most popular terms to show the knowledge assets of a company. Intellectual capital according to Stewart (1997) is a packaged useful knowledge that it includes organizational processes, technology, patents, employees, skills, expertise, and information about customers, suppliers, and stakeholders.

Pulic (1998) takes indirect measurements towards intellectual capital company by measuring the efficiency of the coefficient of company' intellectual capital added value known as Value Added Intellectual Coefficient (VAIC). The main components of VAIC consist of company resources which include physical capital, human capital, and structural capital. An intangible asset account is a reporting post for intellectual capital that can be measured such as patents, trademarks, goodwill and so on while intellectual capital that cannot be measured is disclosed in the notes to the financial statements.

In the global business environment, the implementation of intellectual capital is still something new where only a few developed countries such as Australia, America, and Scandinavia are starting to implement it. It is because there is no right answer regarding the value obtained by the company by applying this concept (Sawarjuwono and Kadir, 2003).

Tourism is one of the important economic sectors in Indonesia, as evidenced in 2009 tourism ranked third in terms of foreign exchange earnings. Cumulatively, during January-December 2012, the number of foreign tourists visiting Indonesia reached 8,044,462 people, which means an increase of 5.16 percent compared to the number of international tourist visits in the same period in 2011 which amounted to 7.65 million. Hotels as a component of tourism have an essential role in the development of tourism in a country. In general, hotels still prioritize the quality of services and products. In addition to this, there is one way that can be used to attract consumers is the construction of physical facilities. To be able to compete with other hotels, in addition to product orientation, market orientation, intellectual capital, and learning orientation are also needed to create innovation, so that hotel performance becomes more optimal (Anshori, 2011).

Wicaksana's research (2011), Ulum (2008), Diez et al. (2010), and Solikhah (2010) provide results that intellectual capital has a positive influence on the growth of the company. Intellectual capital has a positive impact on financial performance and can even be an indicator of future financial performance (Chen et al. 2005; Riahi-Belkaoui 2003). Sunarsih and Mendra's research (2012) explain intellectual capital has a positive impact to financial performance, also Muhammad and Ismail' research (2009) has a same result that intellectual capital has significant and positive relationship with firm performance in Malaysian Financial Sector.

Previous research gives consistent results that intellectual capital gas a positive influence on growth of the company and also has positive impact on financial performance. Therefore, this study tries to collaborate previous research with add the variable performance of the company as an intervening variable that 
can mediate the relationship between intellectual capital with the growth of the company. Companies that can manage their intellectual resources effectively and efficiently, their financial performance will increase. With financial performance increasing, the productivity and efficiency of the company will also increase which will cause the growth of assets owned by the company will also increase.

\section{LITERATURE REVIEW}

\subsection{Intellectual Capital}

Stewart (1997) defines intellectual capital as all intellectual knowledge, all information, and experiences that companies use to create prosperity. According to Pulic (2000), intellectual capital is a collection of employees, organizations, and their ability to create added value. Intellectual capital considered as assets intangible owned and used by companies to generate benefits and improve welfare. Bontis et al. (2000) state that in general, the researchers identified three main constructs of intellectual capital, namely: human capital (HC), structural capital (SC), and customer capital (CC). Human capital represents the individual knowledge stock of an organization reflected by its employees (Bontis et a.l 2001). Human capital is a combination of genetic inheritance, education, experience, and attitude about life and business (Hudson, 1993). Structural capital encompasses all non-human storehouses of knowledge in organizations, including databases, organizational charts, process manuals, routines strategy and all things that make a company's value greater than book value. Customer capital is the knowledge that is inherent in marketing channels and customer relationships that are developed by the organization through its business activities (Bontis et al. 2001). The VAIC ${ }^{\text {TM }}$ method was developed by Pulic (1998), designed to present information about value creation efficiency from tangible assets and intangible assets owned by the company. This model starts with the company's ability to create value added. Value added (VA) is the efficiency of human capital (HC), structural capital (SC) and capital employed (CE).

\subsection{Company Growth}

Company growth is the company's ability to determine company size (Kaliapur and Trombley, 1999). Several indicators can measure the company's growth rate, including Price / Earnings Ratio (Price per Share / Earning per Share), Price / Cash Flow Ratio (Price per Share / Cash Flow per Share), Market to Book Ratio (Market Price per Share / Book Value per Share), Tobins'q (R \& D Expense / Total Sales), and Changes in Total Assets (the difference in the total assets held by the company in the current period and the previous period against the total assets of the previous period).

Growth is expressed as the growth of total assets where the growth of past assets will reflect future profitability and future growth (Taswan, 2003). Growth is a change (decrease or increase) in total assets owned by the company. Asset 
growth is calculated as a percentage change in assets at a given time against the previous year (Saidi, 2004). Based on the explanation above, growth can be interpreted as a change in total assets in the form of an increase or decrease experienced by the company for one period (one year).

\subsection{Company Performance}

Performance is a description of the company in a certain period. Company performance assessment is a periodic determination of the operational effectiveness of an organization, organizational chart, employees based on targets, standards and predetermined criteria (Mulyadi, 1977). Company performance measurements that are commonly used are measurements of the level of liquidity, solvency, profitability and activity (Gitman and Joehnk, 1996). In accordance with the interests of investors towards the growth of its investment value, the measurement of relevant company performance is a measurement of profitability (financial performance), with indicators including ROA, ROE, Residual Income, EVA and MVA.

\subsection{Development of Hypotheses}

The success of a company can be seen through the financial performance in financial statements that are revealed to the public; good financial performance can be seen from the ratio of profitability, liquidity, and solvency. However, the success of the company is not only seen from financial ratios but also the resources owned by the company. The performance of the company is not only produced tangible assets but there are other things that are more important, namely intangible assets owned by the company, namely human resources $(\mathrm{HR})$ that regulate and utilize existing company assets (Baroroh, 2013). The results of Baroroh's study (2013) show that manufacturing companies in Indonesia have the intellectual ability to fulfill the company's operational processes in their routines and the structure can support employees who will produce intellectual performance and optimal business performance and can establish harmonious relationships with corporate partners through physical capital. Based on the explanation above, the first hypothesis in this study is as follows:

$\mathbf{H}_{1}$ : Intellectual capital has a positive influence on company performance

One way to measure company performance can be seen from the level of profitability. Profitability is the ability to earn profits in relation to sales, total assets, and own capital. Companies that can manage their intellectual resources effectively and efficiently, their financial performance will increase. With financial performance increasing, the productivity and efficiency of the company will also increase which will cause the growth of assets owned by the company will also increase. Total assets are chosen as a measure of a company's growth by considering that asset values are relatively more stable than market capitalization values. Based on the explanation above, the second hypothesis in this study is as follows: 
$\mathbf{H}_{2}$ : Intellectual capital has a positive influence on company growth through company performance

\section{METHODOLOGY}

\subsection{Data and Samples}

This study uses secondary data taken from data streams. The research method used is panel data where the data used consists of time series data, namely financial data for the period 2010-2015 and cross-section data, namely data from several companies engaged in hotels, restaurants, and tourism. The population in this study are a hotel, restaurant, and tourism sub-sector service companies listed on the Indonesia Stock Exchange for the period 2010-2015. The selection of samples in this study uses purposive sampling where companies that are sampled must have several criteria.

\subsection{Operationalization of Variables}

The dependent variable used in this study is the growth of companies that use Asset Growth (AG) as a proxy. AG is the difference between the total assets of the company in the current period and the previous period against the total assets of the previous period. The calculation formula for $A G$ is explained as follows:

$$
\left(\frac{\text { Total Asset tahun } \mathrm{t}}{\text { Total Aktiva tahun } \mathrm{t}-1}\right)-1 \times 100 \%
$$

The independent variable is $\mathrm{VAIC}^{\mathrm{TM}}$. The formulation of $\mathrm{VAIC}^{\mathrm{TM}}$ calculation is as follows:

$$
V A I C^{T M}=H C E+S C E+C E E
$$

Remarks:

1. Human Capital Efficiency (HCE) is the ratio of VA to HC. This ratio shows the contribution made by each rupiah invested in $\mathrm{HC}$ to the value-added organizations. The formulation is as follows:

$$
\mathrm{HCE}=\mathrm{VA} / \mathrm{HC}
$$

2. Structural Capital Efficiency (SCE) is the ratio of SC to VA. This ratio measures the number of SCs needed to produce 1 rupiah from VA and is an indication of how successful SC is in value creation. The formulation is as follows:

$$
\text { SCE }=\text { SC } / \text { VA }
$$


3. Capital Employed Efficiency (CEE) is the ratio of VA to CE. This ratio shows the contribution made by each unit of $C E$ to a value-added organization. The formulation is as follows:

$$
\mathrm{CEE}=\mathrm{VA} / \mathrm{CE}
$$

Where:

$$
\begin{array}{ll}
\text { VA } & =\text { OUT }- \text { IN } \\
\text { OUT } & =\text { Total sales and other income } \\
\text { IN } & =\text { Total operating expenses except for salaries and benefits } \\
\text { HC } & =\text { Salaries and employee benefits } \\
\text { SC } & \text { VA- HC } \\
\text { CE } & =\text { book value of net assets }
\end{array}
$$

The intervening variables used in this study are the company's financial performance using profitability ratios, namely Return On Equity (ROE). The formula used to calculate ROE is as follows:

$$
\frac{\text { Laba Pemegang Saham }}{\text { Nilai buku per lembar saham }}
$$

\subsection{Data analysis method}

The tests carried out in this study will use e-views six programs where in this study there are two research models, namely:

\section{Model 1:}

$$
\begin{aligned}
& \text { ROE }_{i t}=\alpha 0+\alpha 1 \text { VAIC }^{\mathrm{TM}}{ }_{i t}+e_{i t} \\
& \begin{array}{ll}
\text { Where: } & \\
\text { ROE } & =\text { Company performance (Return on Equity) } \\
\alpha 0 & =\text { value intercept } \\
\alpha 1 & =\text { Coefficient of intellectual capital } \\
\text { VAIC }^{\mathrm{TM}} & =\text { Intellectual capital (Value-added Intellectual Capital) } \\
\mathrm{e} & =\text { error }
\end{array}
\end{aligned}
$$

Model 1 testing is done to find out whether there is a positive influence of intellectual capital on company performance which can be seen from coefficient $\alpha 1$. If there is a positive influence of intellectual capital on company performance, the coefficient $\alpha 1$ will give a positive sign (+). 


\section{Model 2}

$$
\begin{array}{ll}
A G_{i t}=\beta 0+\beta 1 R^{2} E_{i t}+e_{i t} \\
\text { Where: } & =\text { Corporate growth (Asset Growth) } \\
\begin{array}{ll}
A G & =\text { value Intercept } \\
\beta 0 & =\text { Coefficient of company performance } \\
\beta 1 & =\text { Company performance (Return on Equity) } \\
\text { ROE } & =\text { error } \\
e &
\end{array}
\end{array}
$$

Model 2 testing is a continuation of testing model 1, in testing model 2 used fitted value of ROE generated from testing model 1 . Testing model 2 is done to see the positive effect of company performance on the growth of the company, but the company's performance used is the performance of companies that have influenced by intellectual capital, or it can be said that this test was conducted to determine whether intellectual capital has a positive effect on company growth through company performance. The test results can be seen through the value of $\beta 1$ which gives a positive $(+)$ value if the results match the expectations of the researcher.

\section{RESULT AND DISCUSSION}

After the simultaneous model identification, panel data model selection, and standard assumption testing, regression testing was carried out for both models.

\subsection{First Model}

The first model is tested with fixed effect models with variable techniques dummy (least square variables) based on the tests that have been done before. From the test results in table 11, the probability variable X (VAIC) 0.0018 means that the variable intellectual capital affects on company performance, with coefficient -0.043679 which means that if intellectual capital increases by 1 , the company's performance tends to decrease by 0,043679 . It is not in accordance with the predictions of researchers, and thus hypothesis 1 is rejected, with these results indicating that the use of physical and financial assets still dominates to contribute to the performance of the company. Service companies engaged in hotels, restaurants, and tourism still prioritize physical assets rather than knowledge assets as well as the inability of company managers to optimize intellectual capital to improve company performance.

In addition, the estimation results using the approach fixed effect (least square dummy variable) indicate that not all dummy variables are significant at $\alpha(5 \%)$. Intersep for INPP 0.119304; FAST 0, 364433; MAMI 1,548532; PGLI 0.274083; PJAA 0.173104; PNSE 0.153465; PTSP 0.536713; PUDP 0.40144 
Table 1. First Model Regression Test

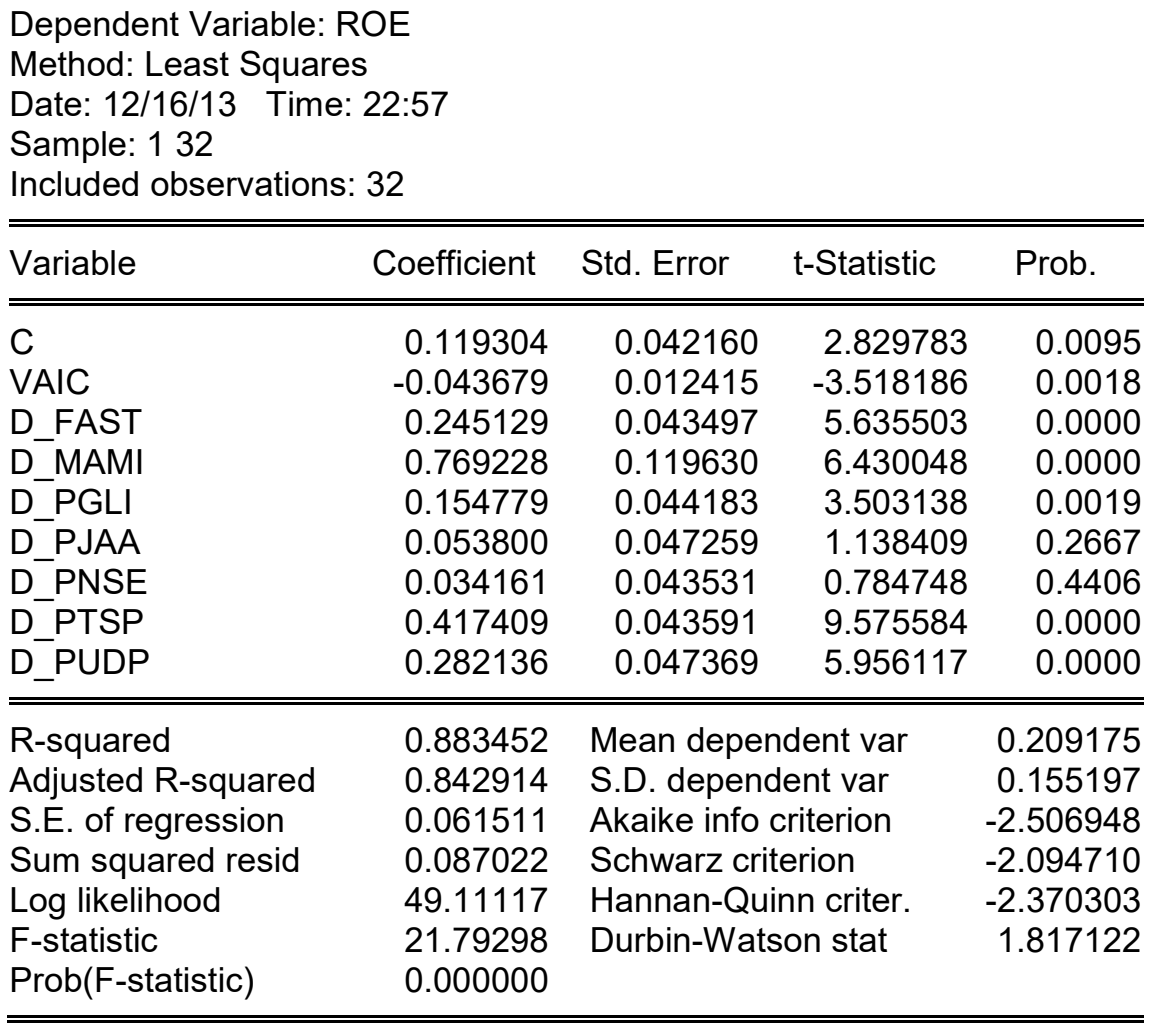

\subsection{Second Model}

After the Chow, Hausman and $L M$ tests were carried out, founded that Pooled Least Square model was the most precise. From the results of testing in table 12, the probability obtained is 0.0932 which means that the variable intellectual capital does not significantly influence the growth of the company through the variable performance of the company. It can be caused because the company's performance cannot mediate the relationship between intellectual capital and company growth. The results of testing the first model can also influence the results of the second regression test.

\section{CONCLUSION}

From several tests carried out in the study, it can be concluded that the intellectual capital variables can affect company performance but have a negative correlation; this can be due to the use of physical and financial assets still dominate to contribute to company performance. Service companies engaged in hotels, restaurants, and tourism still prioritize physical assets rather than knowledge assets as well as the inability of company managers to optimize intellectual capital to improve company performance. 
Moreover, the variable intellectual capital does not significantly influence the growth of the company through the variable performance of the company. It can be caused because the company's performance cannot mediate the relationship between intellectual capital and company growth. The results of testing the first model can also influence the results of the second regression test.

There are some suggestions can be used for subsequent research, including the need to add research samples so that the resulting data can be better and describe the actual conditions. Finally, future research can take other sectors to see how the influence of intellectual capital in various sectors in Indonesia.

\section{REFERENCE}

Anshori, M.Y. 2011. Pengaruh Orientasi Pasar, Intellectual Capital, dan Orientasi Pembelajaran terhadap Inovasi. Jurnal Bisnis Manajemen. Vol. 3 No.3.

Barney. J. 1991. Firm Resources and Sustained Competitive Advantage. Journal of Management. Vol.17.

Bontis,N., Crossan, M and Hulland, J. 2001. Managing an Organizational Learning System by Aligning Stocks and Flows, Journal of Management Studies 39 (4) : 437-469.

Diez, J.M, Magda L.O, M. Begona P, dan Alicia S. 2010. Intellectual Capital and Value Creation in Spanish Firms, Journal of Intellectual Capital. Vol.11, No.3, hlm 348-367.

Fontaine, et al. 2006. The Stakeholder Theory. Retrieved from http://www.edalys.fr/documents/Stakeholders\%20theory.pdf.

Gitmant, L. I, and Joehnk, M. D, 1996, Fundamental of Investing, Sixth Edition, Harper Collins Publisher Inc.

Hudson, W. 1993. Intellectual Capital: How to Build It, Enhance It, Use It, John Wiley, New York.

Kaliapur, et al. 1999. The Assosiation Between Investment Opportunity Set Proxies and Realized Growth. Journal of Business and Accounting. Vol. 26.

Koutsoyiannis, A., 1977. Theory of econometrics: an introductory exposition of econometric methods. Macmillan. London.

Mulyadi. 1997. Manajemen Keuangan Perusahaan, BPFE UGM Yogyakarta. 
Pulic, A. 1998. "Measuring the performance of intellectual potential in knowledge economy". Paper presented at the 2nd McMaster Word Congress on Measuring and Managing Intellectual Capital by the Austrian Team for Intellectual Potential.

Pulic, A. 2000. "VAICTM - an accounting tool for IC management". available online at: www.measuring-ip.at/Papers/ham99txt.htm.

Riahi-Belkaoiu, A. 2003. "Intellectual capital and firm performance of US multinational firms: a study of the resource-based and stakeholder views". Journal of Intellectual Capital. Vol. 4 No. 2. pp. 215-226.

Sawarjuwono, T, Prihatin, A.K. 2003. "Intellectual capital: perlakuan, pengukuran, dan pelaporan (sebuah library research)". Jurnal Akuntansi dan Keuangan. Vol. 5 No. 1. pp. 35-57.

Solikhah, B. 2010. "Pengaruh Intellectual Capital Terhadap Kinerja Keuangan, Pertumbuhan Dan Nilai Pasar Pada Perusahaan Yang Tercatat di Bursa Efek Indonesia”. Tesis. Tidak Dipublikasikan. Universitas Diponegoro. Semarang.

Sunarsih and Mendra. 2012. Pengaruh Modal Intelektual Terhadap Nilai Perusahaan dengan Kinerja Keuangan sebagai Variabel Intervening pada Perusahaan yang Terdaftar di Bursa Efek Indonesia. Proceeding SNA XV. Banjarmasin.

Stewart, T. 1997. Intellectual capital. New York: Doubleday/Currency.

Taswan. 2003. Analisis Pengaruh Insider Ownership, Kebijakan Hutang Dan Deviden Terhadap Nilai Perusahaan Serta Faktor-Faktor Yang Mempengaruhinya. Jurnal Bisnis Dan Ekonomi Vol.10 No.2.

Ulum, et al. 2008. Intellectual Capital dan Kinerja Keuangan Perusahaan; Suatu Analisis dengan Pendekatan Partial Least Squares. Proceeding SNA XI. Pontianak.

Wicaksana, Adityas. 2011. Pengaruh Intellectual Capital Terhadap Pertumbuhan dan Nilai Pasar Perusahaan Pada Perusahaan Perbankan yang Tercatat di BEI. Thesis, Semarang: Universitas Diponegoro. 